\title{
PENGELOLAAN LABORATORIUM KIMIA PADA SMA NEGERI DI KOTA SINGARAJA: (Acuan Pengembangan Model Panduan Pengelolaan Laboratorium Kimia Berbasis Kearifan Lokal Tri Sakti)
}

\author{
${ }^{1}$ I Gusti Lanang Wiratma, ${ }^{2}$ I Wayan Subagia \\ 1,2 Jurusan Pendidikan Kimia, Fakultas Matematika dan IImu Pengetahuan Alam \\ Universitas Pendidikan Ganesha \\ Singaraja, Indonesia
}

e-mail: ramaglan99@gmail.com

\begin{abstract}
Abstrak
Tujuan penelitian ini adalah mendeskripsikan pengelolaan laboratorium kimia SMA yang meliputi aspek pengadaan, penggunaan dan pemeliharaan, serta aspek pemusnahan alat/bahan rusak. Hasil kajian digunakan sebagai acuan membuat draft buku panduan pengelolaan laboratorium kimia berdasarkan konsep Tri Sakti. Jenis penelitian ini adalah penelitian pengembangan (research \& developmen). Penelitian ini dilakukan di kota Singaraja kabupaten Buleleng Provinsi Bali dengan melibatkan empat SMA Negeri yang ada di kota tersebut yaitu, SMAN 1, SMAN 2, SMAN 3, dan SMAN 4 Singaraja. Hasil penelitian menyatakan bahwa pengelolaan laboratorium kimia SMA, secara umum dilakukan melalui rangkaian proses mulai dari aspek pengadaan, penggunaan dan pemeliharaan, dan aspek pemusnahan alat/bahan yang rusak. Dari masingmasing aspek tersebut belum sepenuhnya sempurna sebagaimana mestinya, dan masih ada beberapa kelemahan atau kendala dalam penerapan aspek-aspek pengelolaan laboratorium kimia. Hal ini disebabkan karena komitmen pengambil kebijakan belum optimal dan pemahaman para pihak tentang pengelolaan laboratorium kimia masih rendah.
\end{abstract}

Kata-kata kunci: pengelolaan, laboratorium kimia, kearifan lokal Tri Sakti

\begin{abstract}
The purpose of this study was to describe the management of SMA chemical laboratory covers aspects of the procurement, use and maintenance, as well as aspects of the destruction of equipment/materials damaged. Assessment results are used as a reference manual drafting chemical laboratory management based on the concept of Trisakti. This type of research is the development of research. The research was conducted in the city of Singaraja Buleleng regency of Bali with a group of four high schools in the city are namely, SMAN 1, SMAN 2, SMAN 3, SMAN 4 Singaraja. The research results states that the high school chemical laboratory management, generally through a process of aspects of the procurement, use and maintenance of equipment and facet culling/damaged materials. From each of these aspects has not been completely perfect as it should be, and there are still some weaknesses or problems in the application of the management aspects of the chemical laboratory. This is because understanding of
\end{abstract}


the parties, regarding the management of chemical laboratory is still low and policy makers have not been optimal commitment.

Key words: management, chemical laboratory, local genius Tri Sakti

\section{PENDAHULUAN}

Laboratorium merupakan jantung dari kegiatan pembelajaran sains, khususnya pembelajaran kimia, karena laboratorium merupakan tempat untuk melihat, mencoba, menguji, menilai konsep-konsep sains yang dipelajari hingga siswa memperoleh pemahaman yang lebih baik tentang sains. Belajar sains yang hanya dilakukan melalui membaca buku maupun mendengarkan dari penjelasan guru (sabda) tidaklah lengkap tanpa disertai dengan melakukan kegiatan sains yang sebagian besar dilaksanakan di laboratorium (pratyaksa). Melalui kegiatan laboratorium peserta didik dapat mengkaji kebenaran konsep yang dipelajari secara teroretis melalui analisis kritis berdasarkan kemampuan intelektualnya (anumana). Ketiga cara belajar tersebut dikenal dengan Tripramana (Subagia, 2011; 2003; 2001).

Persoalan yang paling mengemuka dalam pembelajaran di laboratorium adalah masalah kualitas pengelolaan laboratorium yang meliputi proses pengadaan, penggunaan, dan pemeliharaan alat dan bahan. World Health Organization (WHO) menyatakan ada banyak faktor yang berpengaruh terhadap kualitas pengelolaan laboratoriun, antara lain: security, containment, safety, and ergonomics. Security ditekankan pada proses pencegahan resiko dan bahan berbahaya yang tidak diinginkan ketika masuk laboratorium. Containment adalah keinginan untuk meminimalkan resiko dan mencegah ketertinggalan bahan berbahaya di laboratorium yang dapat membahayakan masyarakat. Safety meliputi kebijakan dan procedur untuk mencegah bahaya bagi pekerja, pengunjung, dan masyarakat. Ergonomics ditujukan pada adaptasi terhadap fasilitas dan peralatan untuk menciptakan keselamatan dan kesehatan kerja di laboratorium. Lebih jauh dinyatakan bahwa laboratorium yang tidak menerapkan sistem pengelolaan yang baik berpotensi menimbulkan kesalahan kerja dan masalah lain yang tidak terdeteksi. Sebaliknya, penerapan sistem pengelolaan laboratorium yang baik tidak menjamin bebas dari kesalahan, tetapi dapat mendeteksi dan mencegah kesalahan yang akan terjadi sedini mungkin (WHO, 2011).

Secara umum, persoalan pengelolaan laboratorium kimia SMA dapat muncul pada proses pengadaan, proses penggunaan, dan proses pemeliharaan alat dan bahan. Pada proses pengadaan masalah dapat muncul karena ketidaktepatan pengadaan alat dan bahan. Pada proses penggunaan masalah dapat muncul karena kesalahan pengoperasian alat atau bahan. Pada proses pemeliharaan masalah dapat muncul akibat kesalahan pembersihan dan penempatan alat dan bahan.

Pengamatan di lapangan menunjukkan bahwa alat dan bahan yang tersedia di laboratorium sering 
tidak sesuai dengan kebutuhan dan terkadang banyak tersimpan alat dan bahan yang sudah tidak digunakan. Alat atau bahan yang sudah tidak digunakan, mestinya, dibuang melalui proses pemusnahan yang sesuai dengan aturan agar keseimbangan dan keharmonisan lingkungan laboratorium tetap terjaga. Namun, proses pemusnahan alat atau bahan yang sudah tidak terpakai tampaknya belum diatur atau belum dilaksanakan dengan baik.

Salah satu nilai-nilai kearifan lokal masyarakat Bali yang digunakan sebagai dasar pengaturan keseimbangan dan keharmonisan alam adalah ajaran Trisakti atau Trimurti. Trisakti adalah fungsi kekuatan Tuhan untuk mengatur keseimbangan alam yang terdiri atas tiga kekuatan, yaitu kekuatan mencipta atau mengadakan yang dikenal dengan utpti, kekuatan memelihara atau menjaga yang dikenal dengan stiti, dan kekuatan memusnahkan atau melenyapkan yang dikenal dengan pralina (Soeka, 1986).

Dalam upaya mengembangkan model pengelolaan laboratorium kimia yang tepat, sesuai dengan kondisi di lapangan, maka dipandang perlu untuk mencermati atau memotret pengelolaan laboratorium kimia yang ada di SMAN di kota Singaraja. Potret pengelolaan tersebut di atas akan dapat digunakan sebagai dasar pertimbangan untuk membuat kebijakan pengeloaan pendidikan di sekolah secara umum, dan lebih mengkhusus lagi pada kebijakan pengelolaan laboratorium kimia.

Pembelajaran kimia tidak bisa dilepaskan dari kegiatan praktikum, karena sebagian besar konsep, teori kimia yang dipaparkan di dalam kurikulum mesti dibarengi dengan ujicoba laboratorium. Ujicoba laboratorium dimaksudkan untuk tujuan pembuktian atau verifikasi, dan bisa juga sebagai ajang penemuan. Kegiatan praktikum merupakan kegiatan aplikasi dari teori-teori yang telah dipelajari untuk memecahkan berbagai masalah IPA melalui percobaan-percobaan di laboratorium. Pada hakikatnya kegiatan praktikum di laboratorium mengharapkan para siswa mencapai tujuan-tujuan berikut.

1. Mengembangkan keterampilan dalam pengamatan, pencatatan data, pengukuran dan memanipulasi alat yang diperlukan serta pembuatan alat-alat sederhana.

2. Bekerja dengan teliti, cermat dalam mencatat, serta menyusun hasil percobaan secara jelas dan objektif/jujur.

3. Bekerja secara teliti dan cermat serta mengenal batas-batas kemampuannya dalam pengukuranpengukuran.

4. Mengembangkan kekuatan penalarannya secara kritik

5. Memperdalam pengetahuan inquiri dan pemahaman terhadap cara pemecahan masalah.

6. Mengembangkan sikap ilmiah.

7. Memahami, memperdalam, dan menghayati IPA yang dipelajarinya.

8. Dapat mendesain dan melaksanakan percobaan lebih lanjut dengan menggunakan alat dan bahan yang sederhana (Amien, 1987: 95-96).

Banyak guru mengeluh terkait dengan pembelajaran praktikum di laboratorium, sebagian besar guru kimia

Jurnal Pendidikan Indonesia | 427 
sangat jarang melakukan praktikum kimia sebagaimana tuntutan kurikulum dengan berbagai alasan. Dua alasan utama yang disampaikan oleh guru yaitu: 1) peralatan dan bahan kimia sangat terbatas, 2) terkait dengan sistem evaluasi ujian akhir. Guru beranggapan bahwa pembelajaran dengan praktikum di laboratorium cukup merepotkan dan memerlukan waktu dan tenaga yang banyak, sementara itu untuk keberhasilan menjawab soal ujian akhir bagi anak-anak, lebih efektif dengan cara latihan soal-soal. Para guru kimia sesungguhnya menyadari bahwa praktikum kimia untuk pendalaman materi kimia sangat penting, dan sangat dibutuhkan oleh siswa agar siswa memiliki pengalaman yang langsung berhadapan dengan alam/zat yang sesungguhnya (Wiratma, 2011).

Berdasarkan beberapa hal yang disebutkan di atas maka masalah yang dipecahkan dalam penelitian ini adalah bagaimanakah "potret" pengelolaan laboratorium kimia SMAN di Singaraja? Selanjutnya, dari potret pengelolaan yang diperoleh, ditujukan nanti untuk menyusun model pengelolaan dalam bentuk buku panduan pengelolaan laboratorium kimia SMA.

\section{METODE PENELITIAN}

Penelitian ini merupakan penelitian pengembangan (research \& develompent) yang bertujuan untuk mengembangkan model panduan pengelolaan laboratorium kimia SMA berbasis nilai-nilai kearifan lokal Tri Sakti masyarakat Bali. Pengembangan model panduan ini di awali dengan tahapan memperoleh informasi tentang keadaan pengelolaan laboratorium kimia di SMA Negeri di kota Singaraja sebagai bahan kajian permulaan. Borg dan Gall (1989) merekomendasikan tahapan pelaksanaan penelitian pengembangan sebagai berikut: 1) tahap pengumpulan informasi penelitian, 2) tahap perencanaan, 3) tahap perumusan hasil awal, 4) tahap pengujian lapangan awal, 5) tahap penyempurnaan hasil, dan 6) tahap pengujian lapangan akhir. Sesuai dengan tahapan tersebut, penelitian ini dirancang sebagai berikut. Tahapantahapan penelitian keseluruhan yang dilakukan tersebut adalah sebagai berikut.

Tahap pertama: penelitian pendahuluan dan studi pustaka. Tahap kedua: pelaksanaan penelitian lapangan. Tahap ketiga: perumusan draf buku panduan pengelolaan laboratorium. Tahap keempat: pengujian buku panduan pengeloaan laboratorium oleh ahli. Tahap kelima: pengujian buku panduan pengelolaan laboratorium secara luas Tahap keenam: produksi buku panduan pengelolaan laboratorium kimia SMA.

Penelitian ini dilakukan di Kota Singaraja Kabupaten Buleleng Provinsi Bali dengan melibatkan empat SMA Negeri yang ada di kota tersebut yaitu, SMAN 1, SMAN 2, SMAN 3, dan SMAN 4 Singaraja.

Subjek yang dilibatkan adalah berupa dokumen pengelolaan laboratorium, kepala laboratorium kimia, guru kimia, laboran kimia, dan siswa. Informasi yang dikumpulkan dari tiaptiap subjek adalah isi dokumen pengelolaan laboratorium, pendapat dan pengalaman kepala laboratorium kimia, guru kimia, laboran kimia, dan siswa, yang terkait dengan pengelolaan laboratorium kimia di SMA masingmasing. 
Instrumen dan cara pengambilan data yang digunakan dalam penelitian ini disesuaikan dengan tujuan, subjek, dan objek penelitian. Adapun instrumennya adalah pedoman observasi, pedoman wawancara, dan angket. Pedoman observasi digunakan sebagai panduan melakukan observasi kegiatan laboratorium terhadap laboratorium sekolah yang digunakan sebagai tempat penelitian. Pedoman wawancara digunakan sebagai panduan untuk melakukan wawancara terhadap oknum (informan) yang dilibatkan dalam penelitian ini: kepala laboratorium kimia, guru kimia, laboran kimia, dan siswa. Angket digunakan untuk menggali informasi secara tertulis dari informan yang disebutkan di atas.

Cara analisis data yang digunakan adalah dengan teknik triangulasi yang terdiri atas triangulasi sumber informasi dan triangulasi metode serta analisis deskriptif kualitatif dan interpretatif (Basrowi \& Suwandi. 2008; Miles \& Huberman, 2007).

Analisis dokumen dilakukan dengan memetakan data dokumen pengelolaan laboratorium yang diperoleh dari tiap-tiap sekolah. Berdasarkan analisis tersebut, akan ditemukan kekuatan dan kelemahan pengelolaan laboratorium yang dapat dijadikan acuan pengembangan pedoman. Analisis hasil observasi dan wawancara dilakukan secara bersamasama selama proses pengambilan data dan diperkuat dengan pembuatan transkrip hasil wawancara. Hasil wawancara akan dikuatkan dengan melakukan pengecekan kembali informasi oleh informan (member check). Kridibilitas data ditingkatkan juga dengan cara triangulasi. Analisis akhir dilakukan dengan teknik interpretatif dengan menimbang seluruh data/informasi yang berhasil dikumpulkan. Secara umum, analisis data dilakukan dengan tahapan sebagai berikut: 1) penyajian data, 2) reduksi data, 3) pemetaan (display) data, dan 4) interpretasi data (Sugiyono, 2009; Miles \& Huberman, 2007).

\section{HASIL PENELITIAN DAN PEMBAHASAN}

Beberapa aspek yang digunakan untuk membedah pengelolaan laboratorium kimia SMA yaitu proses pengadaan alat/bahan, proses penggunaan alat/bahan, proses pemeliharaan alat/bahan, dan proses pemusnahan alat/bahan yang sudah aus/rusak. Dalam aspek pengadaan alat dan bahan kimia berdasarkan hasil rekapitulasi angket menunjukkan bahwa proses pengadaan alat/bahan kimia diadakan dengan cara pembelian langsung oleh sekolah, dan dropping dari pemerintah pusat.

Mekanisme yang ditempuh dalam pengadaan oleh sekolah dengan cara membuat analisis kebutuhan yang dilakukan oleh laboran, kepala laboratorium kimia, dan guru kimia. Dilanjutkan dengan membuat usulan (amprah) kepada pimpinan sekolah yang membidangi sarana prasarana, yang selanjutnya diajukan dalam rencana kegiatan anggaran sekolah (RKAS). Dalam proses pembelian ada berbagai variasi cara yang di temukan di lapangan. Ada sekolah melaksanakan pembelian alat/bahan melalui panitia pengadaan, ada yang dibelikan langsung ke distributor oleh wakasek sarana prasarana, dan ada yang dibelikan langsung ke distributor oleh 
bendahara komite sekolah. Pengadaan alat/bahan melalui proses dropping langsung dari pemerintah pusat, sifatnya insidental dan jenis alat/bahan apapun yang datang harus diterima oleh pihak sekolah.

Pengadaan alat dan bahan yang didrop dari pusat sering tidak cocok dengan kebutuhan sekolah, sehingga ada sebagian bahan kimia tidak digunakan, namun harus tetap diterima oleh sekolah.

Penggunaan alat/bahan kimia yang ada di laboratorium kimia, berdasarkan hasil rekapitulasi angket menunjukkan bahwa sebagian besar alat dan bahan digunakan untuk pembelajaran siswa, dan ada sebagian kecil dipakai oleh guru untuk penelitian. Penggunaan alat/bahan dalam pembelajaran praktikum dilaksanakan secara berkelompok dan kadang dengan demonstrasi oleh guru. Data yang dikemukakan di atas ditunjang oleh informasi yang dikemukakan beberapa infporman sebagai berikut.

Mekanisme yang ditempuh dalam proses penggunaan alat/bahan kimia yaitu dengan cara, guru berkoordinasi dengan laboran sehari atau beberapa hari sebelum praktikum, agar laboran menyiapkan alat/bahan yang diperlukan dalam praktikum. Pada saat praktikum siswa mengisi blanko catatan mengenai alat dan bahan yang digunakan, selanjutnya mengambil di tempat yang sudah disediakan. Setelah praktikum selesai siswa wajib membersihkan alat yang digunakan, dan kemudian mengembalikan ke tempat penyimpanan alat. Penggunaan alat/bahan yang dipakai untuk penelitian guru dilakukan melalui koordinasi dengan laboran, dan melakukan pencatatan mengenai bahan dan alat yang digunakan. Ketika penelitian sudah selesai dilakukan, alat dibersihkan dan dikembalikan pada tempat penyimpanan.

Proses pemeliharaan alat/bahan kimia SMA dari hasil rekapitulasi angket diperoleh sebagaian besar pemeliharaan dilakukan oleh laboran, walaupun ada yang menyatakan bahwa pemeliharaan dilakukan oleh guru dan siswa. Beberapa teknik yang dilakukan dalam proses pemeliharaan alat/bahan kimia yakni dirawat bersamaan dengan penggunaan, dan dirawat secara insidental sesuai keperluan.

Khusus untuk kebersihan ruangan dilakukan secara rutin setiap minggu oleh siswa yang diawasi oleh guru/laboran. Mekanisme yang ditempuh dalam proses pemeliharaan dengan penyimpanan di tempat yang tersedia. Temuan di lapangan menunjukkan bahwa ada bervariasi kondisi dalam penyimpanan alat/bahan kimia. Ada sekolah dimana penyimpanan alat dan bahan disimpan berdasarkan pengelompokkan dan ditempat yang aman, dan untuk zat kimia yang bersifat asam ditempatkan pada almari asam. Namun demikian masih ada beberapa sekolah yang menyimpan alat di atas meja, berserakan begitu saja, dan disadari oleh guru maupun laboran bahwa hal tersebut tidak sesuai dengan yang seharusnya. Sebagian besar laboratorium kimia SMAN di Singaraja tidak memiliki almari asam untuk penyimpanan bahan yang bersifat asam kuat. Bahan yang bersifat asam kuat yang ditaruh di rak penyimpanan mengakibatkan terjadi kerusakan pada 
keramik, dinding, dan pintu almari penyimpanan.

Proses pemusnahan alat/bahan kimia yang sudah rusak dilakukan oleh laboran dan ketua lab. Alat/bahan yang sudah tidak layak digunakan kecenderungannya disimpan di tempat tertentu, kemudian dimusnahkan secara insidental sesuai dengan keperluan. Keperluan yang dimaksud dalam hal ini apabila tempat yang dipakai meyimpan bahan/alat yang rusak tersebut sudah tidak memenuhi lagi, ketika hal itu terjadi maka alat/bahan yang sudah rusak dimusnahkan. Mekanisme pemusnahan alat/bahan kimia yang rusak dilaporkan kepada kepala sekolah, jadi pada intinya diketahui oleh kepala sekolah. Dalam proses pemusnahan alat/bahan kimia yang rusak tidak ada teradministrasi tertulis secara formal semacam berita acara pemusnahan barang. Teknik pemusnahan alat yang rusak dilakukan dengan membuang di tempat pembuangan sampah, sementara untuk bahan kimia yang rusak dilakukan dengan menuangkan ke saluran pembuangan, dan ada yang menanam di halaman belakang sekolah. Ada beberapa laboratorium kimia SMAN di singaraja belum dilengkapi septic tank untuk penampungan limbah cair oleh karena itu, limbah cair hasil buangan dari laboratorium mengalir ke saluran umum bersamaan dengan limbah cair yang lain. Dalam proses pemusnahan alat/bahan yang rusak tidak menggunakan peraturan tertentu yang dipakai pedoman.

Pengelolaan laboratorium kimia pada SMAN di Singaraja, dijelaskan secara detail mengenai kegiatan yang sudah berjalan baik dan kegiatan yang belum berjalan optimal. Kegiatan- kegiatan pengelolaan yang telah dilakukan dengan baik, dipakai bahan acuan untuk membuat buku panduan pengelolaan alat/bahan di laboratorium kimia, sementara itu, kegiatan yang belum optimal, dikaji permasalahannya selanjutnya dirancang kegiatan berdasarkan teori pengelolaan laboratorium untuk menghasilkan kegiatan yang dianggap lebih bagus. Ulasan dalam pembahasan dari hasilhasil yang diperoleh, dilakukan berdasarkan kerangka teoritis yang digunakan diantaranya nilai-nilai dalam konsep Tri Sakti, eksistensi laboratorium kimia SMA, dan pengelolaan laboratorium kimia SMA, dengan pemaparan secara deskriptif interpretatif.

Pada aspek pengadaan bahan/alat kimia dari sisi perencanaan berjalan sesuai dengan yang semestinya yaitu guru kimia, ketua laboratorium kimia, dan laboran membuat rencana pengamprahan bahan dan alat kimia yang diperlukan, selanjutnya diajukan kepada sekolah melalui wakasek bidang sarana namun, dalam mekanisme pembelian bahan/alat yang menggunakan sistem panitia terkadang menimbulkan masalah ketika anggota panitia tidak ada yang diwakili oleh guru kimia. Permasalahan yang sering muncul ketika terjadi perubahan pembelian alat/bahan kimia. Hasil dari perubahan terkadang tidak sesuai dengan kebutuhan, atau sering zat-zat kimia tertentu yang jumlahnya banyak sementara zat lain yang diperlukan tidak diadakan. Hal ini terjadi karena masalah hambatan komunikasi dan transfaransi yang terjadi ketika itu. Pembelian alat/bahan kimia yang dibeli langsung oleh wakasek bidang sarana, atau 
mungkin dibeli oleh bendahara komite kepada distributor hasilnya relatif lebih lancar, dan tidak menimbulkan masalah.

Prinsip pengadaan alat/bahan yang diharapkan adalah yang sesuai dengan kebutuhan, lancar, dan tepat waktu. Pengadaan alat/bahan dengan sistem pembentukan panitia, sesungguhnya adalah cara yang tepat, dengan catatan anggota panitia memiliki pemahaman tentang alat/bahan yang akan dibeli. Pengadaan alat/bahan dalam paket besar atau jika uang yang akan dibelanjakan dalam jumlah besar, proses pengadaan alat/bahan mesti dilakukan oleh panitia dan melalui prosedur tender, dan harus mengikuti peraturan pemerintah tentang pengadaan alat/bahan. Jika uang yang akan dibelanjakan tidak terlalu besar, masih berada dalam kategori pembelian langsung kalau merujuk peraturan pengadaan alat/bahan, maka cara dengan pembelian langsung relatif lebih cepat.

Beberapa hal yang perlu diperhatikan dalam perencanaan alat dan bahan kimia untuk praktikum adalah sebagai berikut.

1. Jenis percobaan yang akan dilakukan.

2. Pemahaman mengenai alat dan bahan yang akan dibeli.

3. Daya listrik yang tersedia.

4. Spesifiksi alat/jenis ukuran alat dan bahan yang akan dibeli.

5. Prosedur pembelian.

6. Pelaksanaan pembelian.

Jika dilihat dari konsep kearifan lokal masyarakat Bali, Tri Sakti yang meliputi aspek utpti, stiti, dan pralina. Dalam aspek utpti (penciptaan/ pengadaan) telah dilaksanakan dan telah terjadi proses tersebut, walaupun dalam keterbatasan-keterbatasan. Esensi dari aspek utpti dalam penciptaan adalah kepastian dalam keharmonisan. Oleh karena itu, pengadaan bahan/alat kimia pada laboratorium SMA harus tetap menjaga prinsip keharmonisan di sekolah, tanpa melakukan pelanggaran terhadap aturan yang ada. Dilihat dari prinsip pengelolaan laboratorium kimia SMA, kegiatan perencanaan dalam rangka pengadaan alat/bahan mesti dilakukan dengan prosedur yang tepat dan pemesanan jenis maupun kuantitas bahan yang direncanakan harus pasti. Hal ini diperlukan karena jangan sampai ada bahan yang berlebih, karena sulit menyimpan dalam waktu yang lama dan cenderung merusak lingkungan sekitar.

Pada aspek penggunaan dan pemeliharaan keterlibatan laboran sangat tinggi, dan perannya sangat strategis. Peran laboran dalam proses penggunaan alat dan bahan kimia yang dipakai dalam praktikum, mengawali dengan menyiapkan alat dan bahan yang akan digunakan, mencatat penggunaan, dan diakhir praktikum menata kembali ke tempat semula. Demikian juga dalam pemeliharaan, peran laboran sangat besar terutama dalam menjaga, menata, dan menyimpan alat dan bahan kimia pada tempat yang tepat dan aman. Di beberapa sekolah yang laboratorium kimianya belum memiliki tempat penyimpanan alat/bahan kimia yang tepat dan aman, penyimpanan alat/bahan dilakukan seadanya sesuai dengan tempat yang ada. Kondisi ini terjadi disebabkan oleh komitmen sekolah belum optimal dalam mendukung pengelolaan laboratorium kimia. Pemahaman para pihak

Jurnal Pendidikan Indonesia | 432 
mengenai keamanan, keselamatan kerja, dan lingkungan rendah.

Makna pemeliharaan dalam hal ini bukan berarti alat tersebut disimpan dengan baik sehingga alatnya selalu utuh, akan tetapi alat tetap digunakan dalam waktu yang relatif lama. Teknik pemeliharaan untuk merawat alat/bahan kimia yaitu: menyimpan pada tempat yang aman, menjaga kebersihan, menempatkan secara khusus alat-alat yang berbentuk set, menghindarkan pengaruh lingkungan yang menyebabkan kerusakan alat/bahan.

Untuk pemeliharaan bahan kimia sangat penting memerhatikan sifat bahan yang akan disimpan. Pertama yang diperhatikan adalah wujud bahan dapat berupa padat, cair, dan gas yang harus disimpan dalam kelompok sesuai wujud. Ke dua, menyimpan barang pada tempat dengan kondisi khusus misalnya ruangan dingin berventilasi, jauh dari bahaya kebakaran (api), wadah tertutup, disimpan dalam keadaan tegak berdiri, dan lain-lain sesuai dengan sifat-sifat bahan kimia. Sifat-sifat bahan kimia yang perlu diperhatikan yaitu sifat bahan beracun, korosif, mudah terbakar, mudah meledak, bersifat oksidator, reaktif terhadap air, reaktif terhadap asam, gas bertekanan tinggi dan sensitif terhadap sinar matahari.

Jika dilihat dari aspek stiti (penggunaan dan pemeliharaan) pada konsep kearifan lokal Tri Sakti diperlukan kesadaran, dan dukungan dari banyak pihak yang berkaitan dengan pemeliharaan. Esensi stiti senantiasa dalam keseimbangan dan keharmonisan. Dalam prinsip keseimbangan dan keharmonisan, selalu berpikir kaitannya dengan orang lain dan lingkungan, oleh karena itu diperlukan kerjasama dengan orang lain, dan menjaga kelestarian lingkungan. Keterlibatan dalam pemeliharaan dari orang yang menggunakan sampai pengambil kebijakan diperlukan untuk kenyamanan, keamanan, keselamatan kerja dan lingkungan. Hal ini sesuai dengan yang dipersyaratkan dalam pengelolaan laboratorium kimia. Khamidinal, (2009) dan WHO (2011) ada dua isu sentral yang harus diperhatikan dalam pengelolaan laboratorium, yaitu masalah keselamatan dan kesehatan kerja.

Pada aspek pemusnahan alat/bahan kimia yang rusak peran laboran sangat besar, karena kondisi alat/bahan yang rusak diketahui olehnya, dan kemudian disisihkan disimpan di tempat tertentu. Penyimpanan alat/bahan yang rusak di tempat tertentu dalam waktu yang tidak pasti memunculkan masalah tersendiri. Di samping menghabiskan tempat, juga dapat menimbulkan ketidak nyamanan dan ketidak amanan dalam kerja, karena menimbulkan pencemaran di dalam ruangan. Pada aspek ini dari konsep Tri Sakti yang disebut pralina (peleburan/pemusnahan), sesuatu yang pasti, dan karena itu dalam pemusnahan alat/bahan yang rusak diperlukan kepastian, baik secara aturan maupun cara yang teratur.

Ada beberapa teknik yang dapat digunakan untuk pembuangan limbah bahan kimia sebagai berikut. 1) Insenerasi yaitu metode pembuangan limbah dengn oven berputar pada suhu tinggi. 2) pembuangan pada pipa drainase menuju tempat yang aman biasanya ke septic tank dengan dialiri air seratus kali jumlah limbah yang 
dibuang. 3) Pelepasan uap ke atmosfer dengan cerobong yang relatif tinggi. 4) Pembuangan sampah biasa misalnya dikubur dalam tanah, khusus untuk bahan yang tidak berbahaya.

Keberadaan bahan atau alat yang sudah rusak dan tidak dapat digunakan lagi, cenderung mengganggu kerja, memerlukan tempat, dan cenderung berbahaya bagi kehidupan. Dalam prinsip pengelolaan laboratorium kimia, keamanan, keselamatan kerja dan lingkungan sangat penting diperhatikan. Oleh karena itu pemusnahan alat/bahan kimia yang rusak mesti direncanakan dan dilakukan dengan pasti dengan cara yang tepat.

Temuan lain yang diperoleh bahwa, keberadaan laboratorium kimia SMA belum dikelola dengan baik dan benar. Semua sekolah tempat pengambilan data belum memiliki buku panduan pengelolaan laboratorium kimia. Ketua laboratorium kimia dan laboran telah memiliki buku administrasi laboratorium kimia. Namun demikian, ada satu SMA yang memiliki SOP tentang pengadaan alat dan bahan praktikum, SOP tentang pemusnahan alat/bahan kimia yang rusak dan SOP pelaksanaan praktikum. Komitmen para pihak untuk pemanfaatan laboratorium kimia, pengelolaan laboratorium kimia sebagaimana mestinya belum optimal. Rendahnya komitmen terhadap pengelolaan laboratorium kimia disebabkan oleh rendahnya pemahaman tentang pengelolaan laboratorium kimia, perhatian terhadap kegiatan praktikum kimia relatif rendah. Hal ini disebabkan karena kebijakan evaluasi pendidikan terutama ujian nasional yang sangat sedikit menyentuh aspek praktikum, dan penekanan kompetensi siswa cenderung pada aspek kognitif (Wiratma, 2013).

Dalam proses pembelajaran praktikum di laboratorium tujuannya mengasah ketiga ranah kecerdasan siswa yaitu kognitif, afektif dan psikomotor. Hal lain yang diperoleh dalam praktikum di laboratorium adalah pemahaman yang lebih bermakna mengenai fenomena alam yang dipelajari secara teoritis. Laboratorium adalah tempat untuk melakukan berbagai manipulasi percobaan, baik bersifat pembuktian (verificative) maupun penemuan (discovery). Dalam pembelajaran sains, tidak terkecuali ilmu kimia, laboratorium merupakan bagian yang tidak terpisahkan karena laboratorium hadir sebagai wahana pembuktian konsep-konsep sains yang dipelajari oleh siswa secara teoretis di kelas. Dalam hal ini, laboratorium dapat dilihat sebagai fasilitas pendukung empiris pembelajaran untuk memperkuat pemahaman teoretis siswa yang dipelajari melalui buku-buku teks.

Keberadaan laboratorium kimia di sekolah-sekolah perlu mendapat perhatian khusus karena alat dan bahan kimia yang tersedia di laboratorium kimia sangat berbeda dengan alat dan bahan yang tersedia di laboratorium sains lainnya. Alat-alat laboratorium kimia, umumnya, terbuat dari kaca (gelas) yang mudah pecah sehingga perlu perhatian khusus dalam memakai dan merawatnya (Khamidinal, 2009). Selain alat-alat gelas, dalam laboratorium kimia juga terdapat alatalat lain yang memerlukan tempat perawatan khusus, misalnya neraca analitik, necara Ohaus, spektronik, $\mathrm{pH}$ meter, dan lain-lain, baik yang bersifat analog maupun digital. Bahan-bahan 
kimia yang tersedia di laboratorium, umumnya, memiliki efek samping yang dapat membahayakan penggunaannya. Oleh karena itu pengelolaan laboratorium kimia harus dilakukan dengan baik dan profesional, yang perlu didukung oleh semua pihak.

\section{SIMPULAN DAN SARAN Simpulan}

Berdasarkan penelitian yang dilakukan dapat dinyatakan bahwa, pengelolaan laboratorium kimia SMAN di kota Singaraja, secara umum melalui serangkaian proses mulai dari aspek pengadaan, penggunaan dan pemeliharaan, dan aspek pemusnahan alat/bahan yang rusak. Dari masingmasing aspek tersebut belum sepenuhnya sempurna sebagaimana mestinya, karena masih terdapat beberapa kelemahan atau kendala dalam penerapan aspek-aspek pengelolaan laboratorium kimia. Hal ini disebabkan karena pemahaman para pihak tentang pengelolaan laboratorium kimia masih rendah dan komitmen pengambil kebijakan belum optimal. Namun demikian, ada sekolah yang sudah melakukan pengelolaan laboratorium kimia dengan baik dan aman.

\section{Saran}

Sejalan dengan temuan tersebut, dapat disampaikan saran-saran sebagai berikut. Pertama kepada laboran dan kepala laboratorium kimia, guru kimia perlu meningkatkan pemahaman tentang pengelolaan laboratorium kimia serta selalu melakukan komunikasi dengan pimpinan sekolah dalam rangka pengelolaan laboratorium kimia. Kedua kepada pimpinan sekolah perlu meningkatkan komitmen untuk kepentingan laboratorium kimia, terutama fasilitas pendukung dan pembelajaran praktikum kimia. Ketiga kepada guru kimia agar senantiasa melaksanakan pembelajaran praktikum sesuai dengan kurikulum yang berlaku, agar peserta didik memiliki pengalaman belajar yang lengkap dan memiliki kompetensi yang menyeluruh.

\section{DAFTAR PUSTAKA}

Amien, M. 1987. Mengajarkan IImu Pengetahuan Alam (IPA) dengan Menggunakan Metode Discovery dan Inquiri. Jakarta: Depdikbud.

Basrowi \& Suwandi. 2008. Memahami Penelitian Kualitatif. Jakarta: Reneka Cipta.

Borg, W. R. dan M. D. Gall. 1989. Educational Research: An Introductionl. New York: Longman.

Khamidinal. 2009. Teknik Laboratorium Kimia. Yogyakarta: Pustaka Pelajar.

Miles, M.B. \& A.M. Huberman. 2007. Analisis Data Kualitatif. Diterjemahkan oleh Tjetjep Rohendi Rohadi. Jakarta: UIPress.

Soeka, Gde. 1986. Tri Murthi Tattwa. Denpasar: CV. Kayumas.

Subagia, I Wayan. 2011. Inovasi Model Pembelajaran Berdasarkan Konsep Tri Pramana. Dalam Ajeg Bali dalam Perspektif Pendidikan. Editor Nengah Bawa Atmaja, dkk. Singaraja: Universitas pendidikan Ganesha Press.

Jurnal Pendidikan Indonesia | 435 
Subagia, I Wayan. 2003. Model Siklus Belajar Berdasarkan Konsep "Tripramana." Orasi Ilmiah. Disampaikan dalam rangka Dies Natalis ke-3 IKIP Negeri Singaraja.

Subagia, I Wayan. 2001. Toward a Culturally Relevant TeachingLearning Process for the Teaching of Science in Balinese School: The Applicstion of Balinese Epistemologies to the Teaching of Science. Thesis for Doctor of Philosophy. Australia: La Trobe University.

Sugiyono. 2009. Memahami Penelitian Kualitatif. Bandung: Alfabeta.
WHO. 2011. Handbook Laboratory Quality Management System. Switzerland: WHO Press. www.who.int

Wiratma, I G.L. dan I Wayan Subagia. 2013. Pengembangan Model Panduan Pengelolaan Laboratorium Kimia SMA Berbasis Nilai-nilai Kearifan Lokal Tri Sakti Masyarakat Bali. Laporan Penelitian. Singaraja: UNDIKSHA.

Wiratma, I G.L. 2011. Profesionalisme Guru Kimia SMA Negeri di Kabupaten Buleleng. Jurnal Pendidikan Kimia Indonesia. Ikatan Alumni Jurusan Pendidikan Kimia FMIPA, UNDIKSHA,Vol. 1 No. 1 Hal. 59--66 